\title{
Oxidative Stress and Antioxidant Pathway in Allergic Rhinitis
}

\author{
Munsoo Han (), Dabin Lee, Sang Hag Lee and Tae Hoon Kim* \\ Department of Otorhinolaryngology-Head and Neck Surgery, College of Medicine, Korea University, \\ Seoul 02841, Korea; mshan35@gmail.com (M.H.); dabin425@korea.ac.kr (D.L.); sanghag@kumc.or.kr (S.H.L.) \\ * Correspondence: doctorthk@gmail.com; Tel.: +82-02-920-5486
}

\begin{abstract}
Oxidative stress is the cause and consequence of redox metabolism in various physiological and pathological conditions. Understanding the molecular pathways underlying oxidative stress and the role of antioxidants could serve as the key to helping treat associated diseases. Allergic rhinitis is a condition that deteriorates the daily function and quality of life of afflicted individuals and is associated with a high socioeconomic burden and prevalence. Recent studies have focused on the role of oxidative stress and antioxidants in allergic rhinitis. This review discusses animal and clinical studies on oxidative markers and the potential therapeutic dietary antioxidants for allergic rhinitis.
\end{abstract}

Keywords: oxidative stress; antioxidants; allergic rhinitis

Citation: Han, M.; Lee, D.; Lee, S.H.; Kim, T.H. Oxidative Stress and Antioxidant Pathway in Allergic Rhinitis. Antioxidants 2021, 10, 1266. https://doi.org/10.3390/ antiox10081266

Academic Editors: Marco G. Alves, Pedro F. Oliveira and Luis Crisostomo

Received: 28 June 2021

Accepted: 5 August 2021

Published: 9 August 2021

Publisher's Note: MDPI stays neutral with regard to jurisdictional claims in published maps and institutional affiliations.

Copyright: (c) 2021 by the authors. Licensee MDPI, Basel, Switzerland. This article is an open access article distributed under the terms and conditions of the Creative Commons Attribution (CC BY) license (https:// creativecommons.org/licenses/by/ $4.0 /)$.

\section{Introduction}

Oxidative stress is the cause of a variety of physiological and pathological conditions. An increase in the levels of oxidants may be overwhelming to the natural antioxidant system, leading to direct cellular damage or aberrations in molecular signaling pathways [1]. As scientific research has focused on identifying the molecular pathways underlying oxidative stress, several potential therapeutic antioxidants have been studied. These antioxidants are drawing attention because conventional medical therapies have been inefficient in completely curing a number of diseases.

In that sense, oxidative stress has been studied in conditions such as asthma, one of the respiratory tract inflammatory diseases, severe cases of which are difficult to treat by conventional medical therapies. The role of various biomarkers of oxidative stress, such as nitrotyrosine (Tyr-NO2) and nuclear factor erythroid 2-related factor 2 (Nrf2) in asthma, has been investigated [2,3]. Meanwhile, it is believed that upper and lower airway diseases such as allergic rhinitis, chronic rhinosinusitis, and asthma often co-exist (the "one airway concept") [4]. The majority of asthma patients have allergic rhinitis, and many patients with rhinitis have asthma [5-7]. Considering that allergic rhinitis and asthma may share similar pathophysiology, a theory investigated in asthma is often studied in allergic rhinitis.

Allergic rhinitis is a common health problem characterized by watery rhinorrhea, nasal obstruction, nasal pruritus, and sneezing [8]. It is reported to occur in a great number of people worldwide, which is more than 500 million people across the globe, including approximately $30 \%$ of the population in Western countries, and its high prevalence continues to grow [5,8-10]. Allergic rhinitis causes a considerable economic burden, with an estimated annual cost of approximately $2-5$ billion USD in the United States alone [11]. It is a risk factor for asthma exacerbation [12]. Allergic rhinitis is a critical illness that exerts a negative impact not only on socioeconomic costs but also on an individual's functioning in school or work, sleep, and quality of life $[13,14]$.

Considering the negative influence on health, high prevalence, and socioeconomic cost of allergic rhinitis, its efficient management and control of the disease are crucial. According to the Allergic Rhinitis and its Impact on Asthma (ARIA) guidelines, management of allergic rhinitis includes patient education, medical therapy, and allergen-specific immunotherapy [8]. However, pharmacotherapy for allergic rhinitis, including oral antihistamines and intranasal corticosteroid sprays, is limited in effect, and up to $29 \%$ of children 
and $62 \%$ of adults report partial or poor relief with medical therapy alone $[15,16]$. While treatments such as immunotherapy are reported to be effective in reducing symptoms and the requirement for rescue medication in patients with allergic rhinitis, data on their long-term effectiveness are lacking [17].

Given the current situation in the management of allergic rhinitis, several complementary and alternative medicines have been investigated for the treatment of allergic rhinitis [8]. Antioxidant therapy has recently been applied for allergic rhinitis treatment. As the role of oxidative stress and antioxidants in the pathophysiology of asthma has drawn attention for research, oxidative stress in allergic rhinitis has also been studied because allergic rhinitis is linked to asthma. These studies are expected to improve our understanding of allergic rhinitis and encourage the development of novel therapeutic options. In this article, we have reviewed the current knowledge on the molecular pathways of oxidative stress and antioxidants in allergic rhinitis and the potential therapeutic options with dietary antioxidants for allergic rhinitis.

\section{Oxidative Stress Pathways}

\subsection{Overview of Oxidative Stress}

Oxidative stress arises from oxidation-reduction (redox) homeostasis. The global concept of oxidative stress is defined as "an imbalance between oxidants and antioxidants in favor of the oxidants, leading to a disruption of redox signaling and control and/or molecular damage" $[1,18]$. The concept of ranging oxidative stress in terms of intensity was introduced $[19,20]$. When the balance between oxidants and antioxidants is maintained in a steady-state redox balance, in which stress from oxidants does not overweigh antioxidants, it is of a reversible and physiological state and thus called "oxidative eustress" (Figure 1a) [1]. Oxidative eustress is an important concept in redox control, and it acts as physiological redox signaling [21]. In contrast, when the balance between oxidants and antioxidants deviates to the direction of oxidants, due to excessive and supraphysiological exposure of oxidants or malfunction of antioxidant defense mechanism, aberrant redox signaling or molecular damage occurs, which is termed "oxidative distress".

In oxidative stress, free radicals such as reactive oxygenated species (ROS) are generated by different sources. Despite the complexity in understanding the molecular pathways and biochemical components involved in redox signaling and stress response to oxidants, different sources of oxidants have been identified. As depicted in Figure 1b, diverse endogenous sources of oxidants operate in cells and produce reactive species as normal cellular metabolism, which, in adequate quantity, are essential in cell homeostasis, gene expression, and signal transduction [22]. Opposite to oxidants are antioxidants, which can be categorized into either enzymatic or nonenzymatic [23]. The antioxidant system is associated with counteracting the effects of oxidants. When the endogenous or exogenous source of oxidants is produced in greater quantity or the antioxidant defense mechanism is decreased, oxidative distress occurs. For example, among exogenous sources of oxidants, cigarette smoke is known to contain free radicals, including superoxide and nitric oxide, thus capable of inducing oxidative stress injury in airway epithelium [24]. 
(a)

\section{"Oxidative stress"}

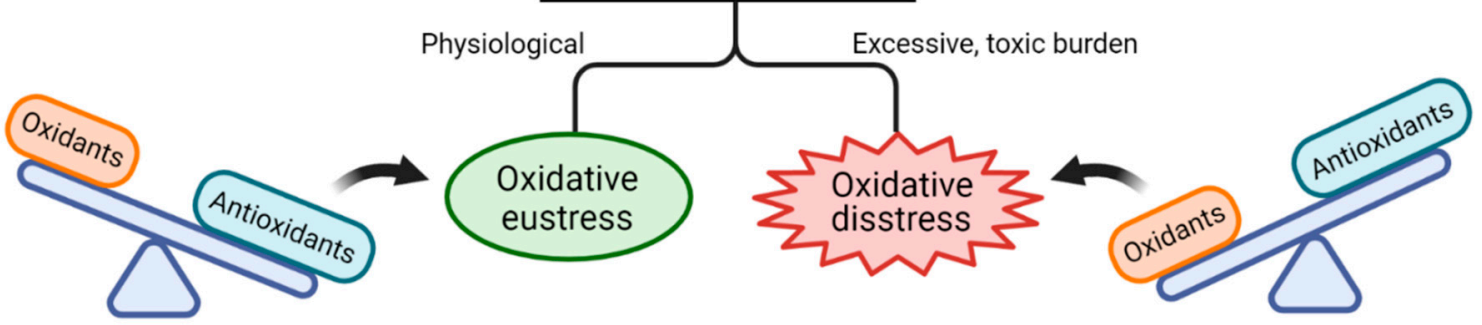

(b)
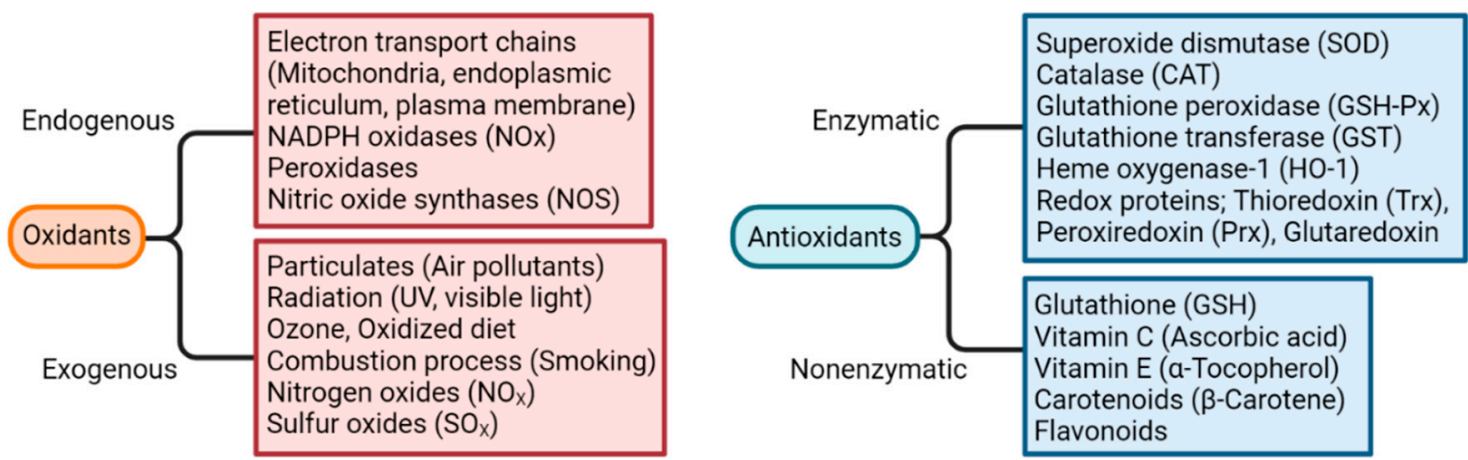

(c)

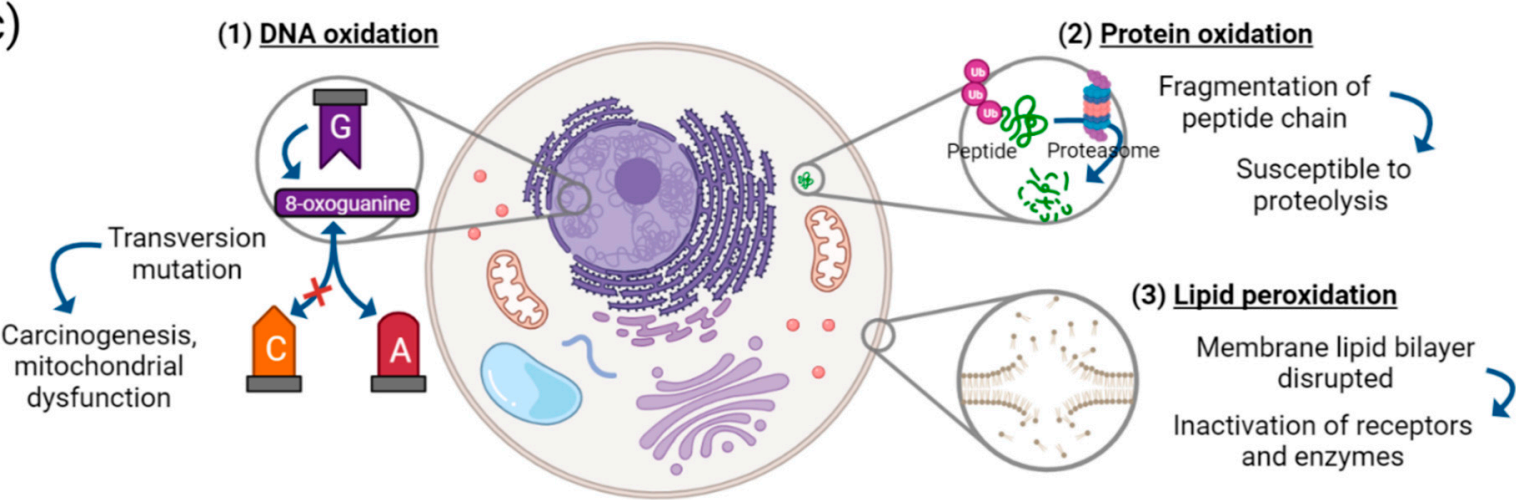

Figure 1. Basic concepts and components of oxidative stress: (a) oxidative stress is distinguished as either oxidative eustress or oxidative distress, depending on the balance between oxidants and antioxidants; (b) sources of oxidants and antioxidants; (c) effect of oxidative damage on biomolecules of DNA, proteins, and lipids. Abbreviation: DNA, deoxyribonucleic acid.

Cellular injury as an effect of oxidative stress can be classified into three categories: damage to nucleic acids, proteins, or lipids (Figure 1c). Oxidation of deoxyribonucleic acids (DNA) can contribute to instability of the genome. One of the examples of DNA oxidation, guanine, among the DNA bases, is most susceptible to oxidative stress [25]. It is transformed into a mutagenic lesion, 8-oxoguanine, after oxidative damage. Instead of paring with cytosine, 8-oxoguanine base pairs with adenine, thus producing transversion mutation when replicated. This oxidatively modified biomolecule is capable of causing mitochondrial dysfunction and tumorigenesis [26].

Oxidation of protein generates oxidation products of amino acid side chains [27]. ROS is capable of causing peptide chain fragmentation, change of electrical charge of proteins, and oxidation of specific amino acids $[23,28]$. This means proteins are susceptible to degradation by proteases, and the oxidatively modified enzymes show decreased activities [29]. Especially among the amino acids, cysteine and methionine are more susceptible to oxidation, and enzymes with metal elements are more sensitive to metal-catalyzed oxidation.

One of the oxygen-derived free radicals is peroxyl radicals (ROO-•); it acts in the peroxidation of fatty acids [23]. Free radicals trigger chain reactions of lipid peroxidation, 
generated lipid radical reacts with oxygen, and peroxyl radicals are produced. Then, peroxyl radical transforms polyunsaturated fatty acids into lipid hydroperoxides, which are unstable and disintegrated into unsaturated aldehydes or malondialdehydes (MDAs). MDAs are one of the commonly used oxidative stress markers [2,30], and are capable of forming cross-linkages of proteins and thus inactivating them [31]. The lipid peroxidation counteracts cell membrane integrity itself, disrupting the membrane lipid bilayer and downregulating membrane receptors and enzymes.

\subsection{Oxidative Stress and Possible Therapeutic Antioxidants in Diseases}

A great amount of health and disease states have been covered in the literature regarding the field of molecular pathways of oxidative stress. Biomarkers of oxidative stress, either protein, lipid, or DNA, have been analyzed in numerous diseases in humans. Some studies examined if specific oxidative markers are related to specific diseases, and cluster analysis was performed to compare the clinical relevance of oxidative stress markers and the correspondence among diseases [2]. Among them, studies regarding asthma are worth attention. As for biomarkers of oxidative stress in asthma, in a recent study, oxidative stress and antioxidant capacity were measured in asthma patients and healthy individuals [32]. MDA and protein carbonyl (PC) levels were significantly increased in asthma patients, but glutathione (GSH) levels were decreased (Figure 2).

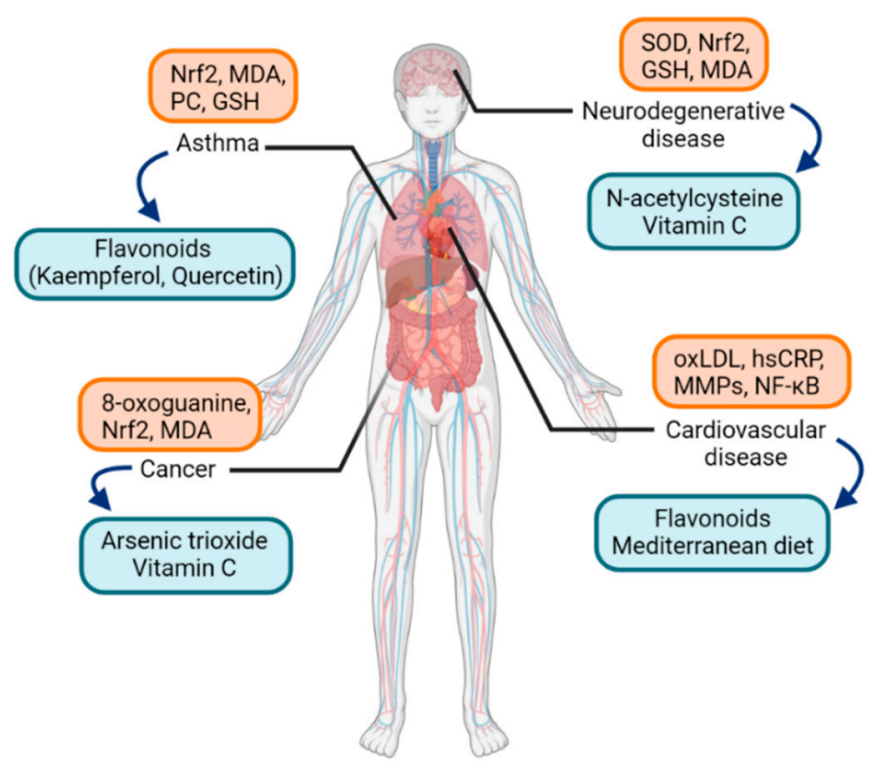

Figure 2. Examples of oxidative-stress-related diseases and associated oxidative stress markers (orange box) along with possible therapeutic antioxidants (blue box). Abbreviations: Nrf2, nuclear factor erythroid 2-related factor 2; MDA, malondialdehyde; PC, protein carbonyl; GSH, glutathione; SOD, superoxide dismutase; oxLDL, oxidized low-density-lipoprotein; MMPs, matrix metalloproteinases; NF- $\mathrm{B}$, nuclear factor kappa-light-chain-enhancer of activated B cells.

Asthma is a relatively common disease characterized by airway hyperresponsiveness and airway inflammation and remodeling. The pathogenesis of asthma involves activation of various inflammatory cell infiltration and production of different cytokines [33]. In the pathogenesis of asthma, intracellular signaling cascades involving Toll-like receptors (TLRs) and transcription factors such as nuclear factor kappa-light-chain-enhancer of activated B cells (NF- $\mathrm{kB}$ ) are important [34]. Potent exogenous oxidants such as cigarette smoke and ozone increase the expression of TLRs and contribute to the redox balance in the lungs $[35,36]$. Furthermore, as a redox-sensitive transcription factor, NF- $\mathrm{KB}$ is activated by ROS to result in chromatin remodeling and expressing proinflammatory mediators [37,38]. Another transcription factor, Nrf2, regulates antioxidant response, including maintenance 
of epithelial barrier integrity and proliferation in smooth muscle cells in the airway, and was found to exert aberrant activity in asthma [39,40].

While conventional therapy of asthma comprises inhaled or systemic corticosteroids, inhaled $\beta 2$-adrenoceptor agonists, and leukotriene receptor antagonists [41], the effectiveness of these conventional treatment methods is rather unsatisfactory in patients with severe asthma $[42,43]$. The need for a novel alternative therapeutic option could be met by targeting the signaling pathways of oxidative stress in asthma [34]. Among the studies on antioxidants in asthma, yielding relatively strong antioxidant properties are dietary flavonoids. Flavonoids have antioxidant activities to regulate cellular signaling pathways involving transcription factors such as NF- $\mathrm{kB}$. Examples of flavonoids are quercetin and kaempferol, and especially the latter showed to alleviate airway inflammation in an animal allergic asthma model [44]. A limited number of clinical trials have been promoted for flavonoids in asthma patients and showed improvements in serum leukotriene levels, peak expiratory flows, or asthma symptom scores $[45,46]$. As allergic rhinitis shares similar pathogenesis as asthma in terms of airway inflammation, encouraging results of studies about antioxidants in asthma gives a direction of research for allergic rhinitis.

As for other diseases known to be associated with oxidative stress, Alzheimer's disease is one of the most prevalent neurodegenerative diseases. It shows symptoms of dementia, impaired spatial memory, and cognitive deficits [47]. It has been reported that DNA damage, lipid peroxidation, and protein nitration are increased in Alzheimer's disease [48]. Another significant neurodegenerative disease is autism. Autism spectrum disorders are neurodevelopmental disorders with impairments in social interaction, language, perception, and behaviors. Mitochondrial dysfunction represented by decreased expression of electron transport complexes and superoxide dismutase (SOD) in mitochondria was noted, leading to elevated production of ROS [49]. Possible antioxidant treatment to reduce oxidative stress and improve mitochondrial function includes ascorbic acid and $\mathrm{N}$-acetylcysteine [50,51].

In cardiovascular diseases, elevated production of ROS leads to oxidative damage and is known to worsen ischemia-reperfusion injury in myocardial infarction [52]. Atherosclerosis, as the leading cause of mortality from cardiovascular disease, is also affected by inflammatory mechanisms derived from oxidative stress [53]. Oxidized cholesterol, or oxysterol, including oxidatively modified low-density lipoprotein (oxLDL) molecules, activates endothelial cells by releasing bioactive phospholipids, and then circulating monocytes differentiate into macrophages, which is an important pathogenesis in atherosclerosis [54,55]. Additionally, protein biomarkers, such as high sensitivity C-reactive protein (hsCRP) or matrix metalloproteinases (MMPs), and transcriptional factors such as NF- $\mathrm{kB}$, are well-known in the pathogenesis of atherosclerosis; hsCRP binds to oxLDL and promotes endothelial dysfunction [56]. As for therapeutic antioxidants, there is still controversy about whether antioxidants are an effective treatment modality in cardiovascular diseases. Recent reviews and meta-analyses showed results of reduced mortality due to cardiovascular diseases by supplementing antioxidants such as flavonoids, green teas, or the Mediterranean diet [57-59]. Experimental studies identified that oxidant and proinflammatory mediators such as ROS and $\mathrm{H}_{2} \mathrm{O}_{2}$ are produced in cardiac tissues and murine macrophages, and the antioxidant resveratrol reduced the production of the oxidants [60].

In terms of malignancy, various redox-oriented cancer therapies have been evaluated in clinical settings [61,62]. One of the agents with potential redox activity that showed a promising result with US Food and Drug Administration (FDA) approval for acute promyelocytic leukemia is arsenic trioxide [63]. Vitamin C was studied in colon cancer; at high doses, it acts as an oxidant, yielding potential anticancer activity [64]. Other anticancer drugs with potential clinical activities were covered in a recent review [65]. 


\section{Allergic Rhinitis and Oxidative Stress}

\subsection{Pathophysiology of Allergic Rhinitis}

Allergic rhinitis is an immunoglobulin E ( $\operatorname{gE}$ )-mediated inflammation of the nasal mucosa induced by allergen inhalation $[8,66]$. A variety of components involving cells of the nasal cavity and inflammatory cells, cytokines, mediators, and cell adhesion molecules participate in the process of allergic rhinitis. As depicted in Figure 3a, the pathogenesis of allergic rhinitis begins with allergen sensitization $[12,67]$. Inhaled allergens in the nasal epithelium are captured by dendritic cells, which act as antigen-presenting cells, and are presented as allergenic peptides to T lymphocytes [68]. This induces T helper 2 (Th2) cells, which secrete Th2 type cytokines such as interleukin (IL)-4, IL-5, IL-10, and IL-13. This process converts B lymphocytes into allergen-specific IgE-producing plasma cells. The released allergen-specific IgE molecules bind to tissue mast cells and circulating basophils.

(a)

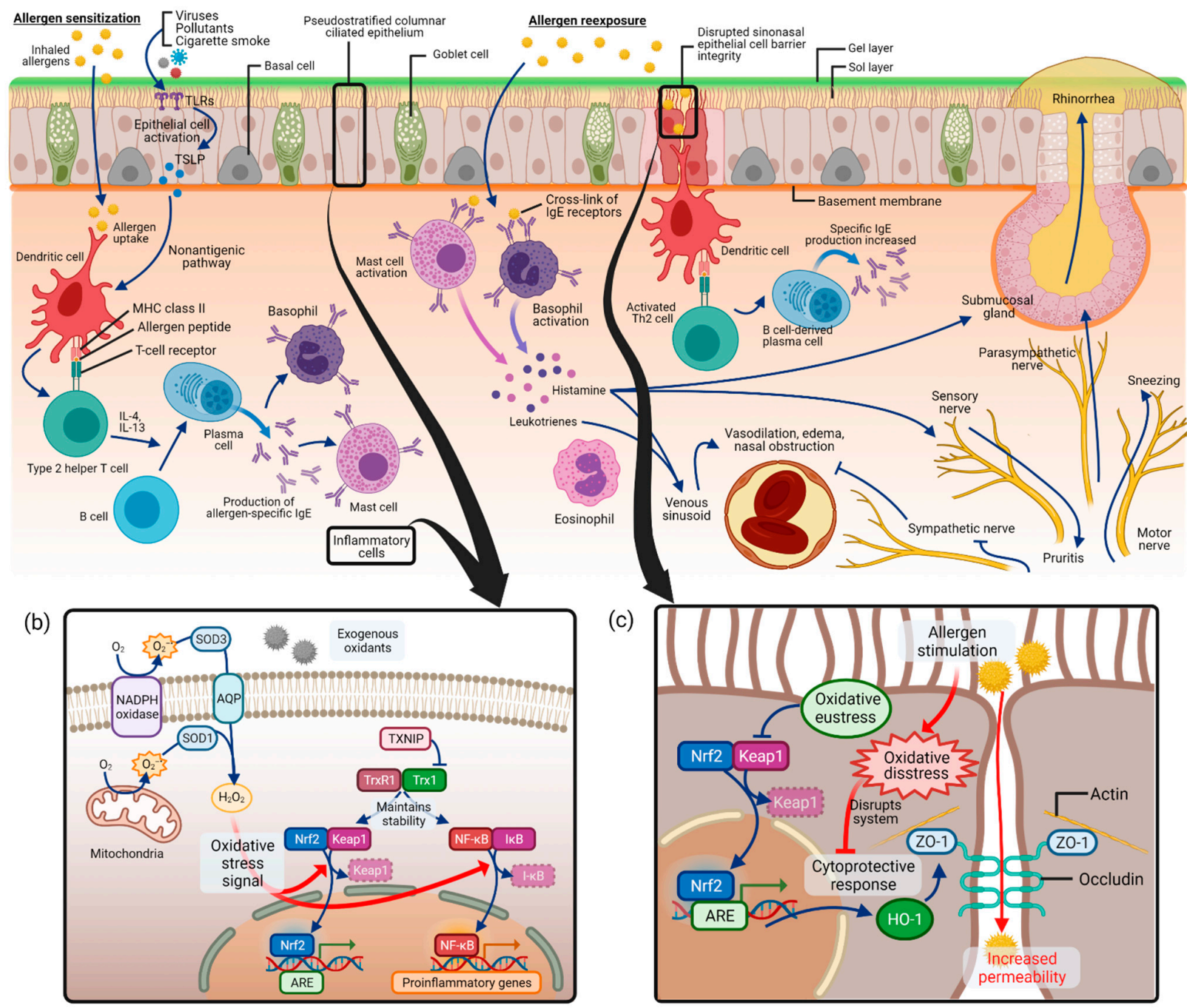

Figure 3. Allergic rhinitis and oxidative stress pathways: (a) pathogenesis of allergic rhinitis as in allergic sensitization followed by allergen reexposure; (b) regulation of signaling pathways by Nrf2 and NF- $\mathrm{BB}$ in oxidative stress of allergic rhinitis; (c) disrupted sinonasal epithelial cell barrier integrity in allergic rhinitis and associated oxidative stress pathway. Abbreviations: NADPH, nicotine adenine dinucleotide phosphate; SOD, superoxide dismutase; $\mathrm{AQP}$, aquaporin; $\mathrm{H}_{2} \mathrm{O}_{2}$, hydrogen peroxide; TXNIP, thioredoxin-interacting protein; TrxR1, thioredoxin reductase 1; Trx1, thioredoxin 1; Nrf2, nuclear factor erythroid 2-related factor 2; Keap1, Kelch-like ECH-associated protein 1; NF-kB, nuclear factor kappa-light-

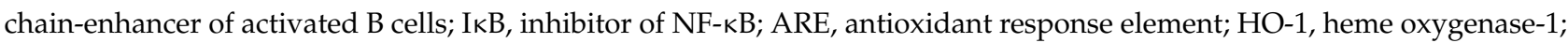
ZO-1, zonula occludens-1. 
Upon allergen reexposure, the same allergen binds to the surface IgE on mast cells and basophils and activates the cells. Various kinds of neuroactive and vasoactive mediators, such as histamine and leukotriene, are released from the cells. Typical allergic rhinitis symptoms, such as nasal congestion, rhinorrhea, or itching, are produced by substances that act on vessels and glands of the nose. In addition, Th2 lymphocytes are activated by dendritic cells, and consequently release cytokines and chemokines, which mediate the recruitment of inflammatory cells such as T cells, B cells, eosinophils, basophils, and neutrophils to the nasal mucosa, further progressing allergic rhinitis reactions.

\subsection{Oxidative Stress and Allergic Rhinitis}

Most disease states include redox component at some degree or stage, and it is important to understand the complex multifactorial concept of oxidative stress that in a disease state, oxidant and antioxidant factors could act at the same time, leading to oxidative eustress or distress depending on which factor is stronger [1]. It also helps to note that the antioxidant system can operate in a paradoxical way from what was expected, according to its quantity, stage, or tissue $[69,70]$.

Due to its complexity and multifactorial components in understanding the molecular pathways and signals of oxidative stress, and since allergic rhinitis is a relatively less explored topic for studying oxidative stress, recent studies regarding oxidative stress in allergic rhinitis have focused on identifying the change of the quantity of known oxidants and antioxidants in allergic rhinitis states and after treatment with dietary antioxidants. After reviewing the literature on oxidative stress pathways and the potential therapeutic antioxidants in allergic rhinitis, we combined the results of the studies with previously known molecular pathways of oxidative stress, as schematically shown in Figure 3.

ROS production by mitochondria and nicotine adenine dinucleotide phosphate (NADPH) oxidase was first discovered in phagocytes but later turned out to be present in different epithelial and inflammatory cells (Figure 3b) [1]. Superoxide anion $\left(\mathrm{O}_{2}-\bullet\right)$ is produced by adding one electron to molecular oxygen $\mathrm{O}_{2}$, mediated by the mitochondrial electron transport system or NADPH oxidase [23,71]. Approximately 1-3\% of electrons leak from the mitochondrial electron transport system and produce superoxide instead of being reduced [23]. Then, superoxide is converted to hydrogen peroxide $\left(\mathrm{H}_{2} \mathrm{O}_{2}\right)$ by SODs. Extracellular $\mathrm{H}_{2} \mathrm{O}_{2}$ is captured and imported into the cytoplasm by aquaporins (AQPs) [72]. As a major signaling molecule in redox signaling, $\mathrm{H}_{2} \mathrm{O}_{2}$ acts as a messenger in a variety of oxidative eustress (physiologic, health condition) and distress (pathologic condition) pathways [21]. It is capable of regulating the activity of several transcription factors such as Nrf2 and NF-kB [73].

As commonly known signaling pathways in oxidative stress, Nrf2/Keap1 (Kelch-like ECH-associated protein 1) and NF- $\mathrm{KB}$ pathways have been covered in allergic rhinitis. What is known in general is that Nrf2/Keap1 and NF-kB pathways serve as "molecular redox switches" which control activation or deactivation cycles and modulate system activities in a broad range of biological conditions [1] (p. 730). In unstressed conditions, Nrf2 is suppressed in transcriptional function due to ubiquitination and degradation by Keap1 [74]. Under oxidative stress, Keap1 is modified and no longer capable of ubiquitinating Nrf2, leading to the release of Nrf2 and its accumulation in the nucleus, which acts as a transcription factor to induce antioxidant and detoxication enzymes [75]. In this signaling cascade, thioredoxin reductase 1 (TrxR1) was reported to be a regulator for Nrf2 [76].

For allergic rhinitis, the role of thioredoxin-interacting protein (TXNIP) was evaluated in oxidative stress [77]. In the ovalbumin (OVA)-induced allergic rhinitis murine model, expression of TXNIP in nasal mucosa, MDA level, and SOD activity were measured, along with allergic rhinitis markers such as nasal symptoms of sneezing and nasal rubbing, OVAspecific IgE and histamine in serum, and OVA-specific IgE, IL-4, IL-5, and tumor necrosis factor (TNF)- $\alpha$ in the nasal lavage fluid. The outcomes were measured between mice that received intranasal administration of a TXNIP inhibitor, resveratrol, and those without treatment. In the untreated allergic rhinitis group, nasal symptoms, TXNIP and OVA- 
specific IgE levels, histamine and cytokine levels, and MDA levels were increased, and SOD level was decreased, but these results were attenuated in the resveratrol-treated group. In the nasal tissue, epithelial cells and inflammatory cells were found to be TXNIP-positive. This result implies that the regulation of transcription factors of oxidative stress pathway by thioredoxin and TXNIP is relevant in allergic rhinitis, although the understanding of the exact signaling pathway between the transcription factors and allergic rhinitis markers such as cytokines, inflammatory cells, and nasal symptoms warrants further research.

Another transcription factor, NF- $\mathrm{kB}$, is also capable of being activated in response to oxidative stress. After oxidation by $\mathrm{H}_{2} \mathrm{O}_{2}$, the inhibitory subunit of the NF- $\mathrm{kB}$ inhibitor $(\mathrm{I} \kappa \mathrm{B})$ is released [78]. Then, NF- $\mathrm{KB}$ is freed and allowed to enter the nucleus, acting as a transcription factor and expression of genes involved in inflammatory, immune, or acute-phase responses [79-81].

In allergic rhinitis, several recent studies covered the activity of the NF- $\mathrm{kB}$ pathway in the allergic rhinitis murine model [82,83]. It was reported in the studies that in the OVA-induced allergic rhinitis model, oxidative stress markers such as MDA level and Nrf2 and NF- $\mathrm{kB}$ pathways are upregulated. They were associated with inflammatory signs such as cytokine levels and histopathology findings in allergic rhinitis models. After treatment with an antioxidant, mangiferin, the markers were downregulated.

In the pathogenesis of allergic rhinitis, antigen presentation by dendritic cells is the first step in allergen sensitization. It has been reported that physical epithelial barrier dysfunction in the nasal epithelium may contribute to the uptake of allergens and harmful exogenous particles in allergic rhinitis (Figure 3c) [84-86]. In allergic rhinitis patients with house dust mite allergy, epithelial barrier function impairment was found with increased epithelial permeability and altered occludin and zonula occludens (ZO)-1 expression [87]. This disrupted mucosal integrity could contribute to the decreased response to medical therapy, making it an important study area for the treatment of allergic rhinitis. Several studies have investigated the role of oxidative stress in epithelial cell barrier dysfunction in allergic rhinitis (Figure 3c).

The nasal epithelial cell barrier is made up of cell-to-cell tight junctions, which are formed with scaffold adaptor proteins ZO-1, ZO-2, and ZO-3 and integral membrane proteins such as occludin $[86,88]$. In a recent study, human sinonasal epithelial cells were used to study epithelial cell barrier function under allergic conditions [89]. After stimulation with house dust mite, the authors stained epithelial cells for the epithelial cell junction protein ZO-1 and measured epithelial cell permeability. Stimulation with house dust mite resulted in global disruption of $\mathrm{ZO}-1$ and increased permeability in sinonasal epithelial cells.

Another study used the OVA-induced allergic rhinitis mouse model and investigated various outcomes, including epithelial cell permeability, after administration of a possible antioxidant, Piper nigrum extract [90]. By enhancing the Nrf2 transcription factor pathway, anti-inflammation enzyme heme oxygenase (HO)-1 synthesis was increased. As a consequence, ZO-1 and occludin degradation was inhibited, and the epithelial barrier integrity was enhanced.

According to the previous experimental and clinical studies which we have reviewed above, several oxidative stress markers were identified and found to be increased in allergic rhinitis. It is difficult to say that the markers are specific to allergic rhinitis since NF- $\mathrm{kB}$ and Nrf2 pathways are also found in oxidative stress pathways in other inflammatory disease conditions. Nrf2 is a well-known, clinically relevant biomarker of oxidative stress in diseases such as chronic obstructive pulmonary disorder, cancer, or Alzheimer's disease [91-93]. Because a number of oxidative stress markers are relevant in various diseases and similar diseases might share the same relevant oxidative stress markers, future researchers can refer to biomarkers of asthma, which share similar pathogenesis to allergic rhinitis [2]. 


\subsection{Therapeutic Antioxidants in Allergic Rhinitis}

Most of the studies regarding oxidative pathways in allergic rhinitis have focused on finding potential dietary antioxidants as an alternative pharmacotherapy option for controlling the disease. Therefore, current literature is somewhat limited in defining the complex and diverse molecular pathways of oxidative stress specific to allergic rhinitis. Recent studies which dealt with those dietary antioxidants in allergic rhinitis were reviewed, and the details, including the natural diet source of each antioxidant, are described in Table $1[77,82,83,89,94-98]$.

Table 1. Recent studies regarding the potential therapeutic antioxidants in relation to oxidative stress in allergic rhinitis.

\begin{tabular}{|c|c|c|c|c|}
\hline $\begin{array}{l}\text { Exogenous } \\
\text { Antioxidants }\end{array}$ & Diet Source & Authors (Year) & Study Designs & Therapeutic Antioxidant Effects \\
\hline \multirow[b]{2}{*}{ Sulforaphane } & \multirow[b]{2}{*}{$\begin{array}{l}\text { Broccoli, } \\
\text { cabbage }\end{array}$} & $\begin{array}{l}\text { Yusin, J. et al. } \\
\text { (2021) [94] }\end{array}$ & $\begin{array}{l}\text { Clinical trial } \\
\text { (double-blind, } \\
\text { randomized, } \\
\text { placebo-controlled) }\end{array}$ & $\begin{array}{l}\text { Clinical measurements (TNSS, PNIF) of AR } \\
\text { patients improved after sulforaphane } \\
\text { supplementation. } \\
\text { In nasal mucus fluid, T2 cytokines such as IL-4, } \\
\text { IL-5, and IL-13 were decreased, but there was } \\
\text { no statistical significance. }\end{array}$ \\
\hline & & $\begin{array}{l}\text { London, N.R., Jr. } \\
\text { et al. (2017) [89] }\end{array}$ & $\begin{array}{l}\text { Human study } \\
\text { (tissue-specific) }\end{array}$ & $\begin{array}{c}\text { Human SNECs were harvested and stimulated } \\
\text { with HDM with/without Nrf2 activation with } \\
\text { sulforaphane. } \\
\text { Epithelial cell junction protein ZO-1 was } \\
\text { disrupted with HDM stimulation but increased } \\
\text { when treated with sulforaphane before } \\
\text { stimulation with HDM. Similar beneficial effect } \\
\text { was found with transepithelial electrical } \\
\text { resistance. }\end{array}$ \\
\hline \multirow[b]{2}{*}{ Resveratrol } & \multirow{2}{*}{$\begin{array}{l}\text { Grapes, } \\
\text { berries, } \\
\text { peanuts }\end{array}$} & $\begin{array}{l}\text { Zhang, W. et al. } \\
\text { (2020) [77] }\end{array}$ & $\begin{array}{l}\text { Animal study } \\
\text { (OVA-induced } \\
\text { murine AR model) }\end{array}$ & $\begin{array}{l}\text { After resveratrol treatment, TXNIP, MDA, SOD, } \\
\text { inflammatory cytokines, eosinophil numbers, } \\
\text { and nasal symptoms were significantly altered } \\
\text { compared to untreated AR mice. }\end{array}$ \\
\hline & & $\begin{array}{l}\text { Lv, C. et al. (2018) } \\
\text { [95] }\end{array}$ & $\begin{array}{l}\text { Clinical trial } \\
\text { (double-blind, } \\
\text { randomized, } \\
\text { placebo-controlled) }\end{array}$ & $\begin{array}{l}\text { AR patients treated with resveratrol showed } \\
\text { reduction in nasal symptoms, serum IgE, IL-4, } \\
\text { TNF- } \alpha \text {, and eosinophil levels. }\end{array}$ \\
\hline \multirow[t]{2}{*}{ Mangiferin } & \multirow[t]{2}{*}{ Mango } & $\begin{array}{l}\text { Piao, C.H. et al. } \\
\text { (2020) [82] }\end{array}$ & $\begin{array}{l}\text { Animal study } \\
\text { (OVA-induced } \\
\text { murine AR model) }\end{array}$ & $\begin{array}{c}\text { Mangiferin treatment led to reduction of nasal } \\
\text { symptoms, nasal mucosa inflammation, } \\
\text { inflammatory cell infiltration, and epithelial } \\
\text { disruption in histopathology. } \\
\text { In NALF, MDA level reduced, SOD activity } \\
\text { increased, and Nrf2/HO-1 expression was } \\
\text { upregulated, while expression of NF-kB was } \\
\text { decreased. }\end{array}$ \\
\hline & & $\begin{array}{l}\text { Wang, Y. et al. } \\
(2020)[83]\end{array}$ & $\begin{array}{l}\text { Animal study } \\
\text { (OVA-induced } \\
\text { murine AR model) }\end{array}$ & $\begin{array}{l}\text { After administration of mangiferin, MDA level } \\
\text { was decreased, and NF- } \mathrm{KB} \text { pathway was } \\
\text { prevented, which led to downregulation of } \\
\text { TNF- } \alpha \text { and IL-1 } \beta \text {. } \\
\text { In histopathology, ciliary loss and eosinophil } \\
\text { infiltration were decreased. }\end{array}$ \\
\hline $\begin{array}{c}\text { Piper nigrum } \\
\text { extract }\end{array}$ & Black pepper & $\begin{array}{l}\text { Bui, T.T. et al. } \\
(2020)[90]\end{array}$ & $\begin{array}{l}\text { Animal study } \\
\text { (OVA-induced } \\
\text { murine AR model) }\end{array}$ & $\begin{array}{c}\text { After Piper nigrum extract treatment, mast cells } \\
\text { histamine release, nasal symptoms in early } \\
\text { phase reaction, and eosinophil accumulation in } \\
\text { nasal lavage fluid and nasal tissue were } \\
\text { decreased. }\end{array}$ \\
\hline
\end{tabular}


Table 1. Cont.

\begin{tabular}{|c|c|c|c|c|}
\hline $\begin{array}{c}\text { Exogenous } \\
\text { Antioxidants }\end{array}$ & Diet Source & Authors (Year) & Study Designs & Therapeutic Antioxidant Effects \\
\hline Quercetin & $\begin{array}{l}\text { Onions, red } \\
\text { wine, tea }\end{array}$ & $\begin{array}{c}\text { Edo, Y. et al. } \\
\text { (2018) [97] }\end{array}$ & $\begin{array}{l}\text { Human study } \\
\text { (tissue-specific) } \\
\text { Animal study } \\
\text { (OVA-induced } \\
\text { murine AR model) }\end{array}$ & $\begin{array}{c}\text { Human SNECs showed increased TRX } \\
\text { production in ELISA when treated with } \\
\text { quercetin. } \\
\text { In animal model, quercetin was orally } \\
\text { administered, and the nasal symptoms were } \\
\text { inhibited. In NALF, TRX levels were increased. }\end{array}$ \\
\hline Taurine & $\begin{array}{l}\text { Scallops, tuna, } \\
\text { octopus }\end{array}$ & $\begin{array}{l}\text { Zhou, J. et al. } \\
\text { (2020) [98] }\end{array}$ & $\begin{array}{l}\text { Human study } \\
\text { (serum marker) } \\
\text { Animal study } \\
\text { (OVA-induced } \\
\text { murine AR model) }\end{array}$ & $\begin{array}{l}\text { In AR patients compared to healthy controls, } \\
\text { after treatment of taurine, serum SOD3 level } \\
\text { was decreased. } \\
\text { In animal model, AR symptoms, inflammatory } \\
\text { cytokines (TNF- } \alpha \text {, IL-4, and IL-6), and } \\
\text { eosinophil and mast cell infiltration in nasal } \\
\text { mucosa were decreased. SOD3 production was } \\
\text { increased. }\end{array}$ \\
\hline
\end{tabular}

Abbreviations: TNSS, total nasal symptom score; PNIF, peak nasal inspiratory flow; AR, allergic rhinitis; IL, interleukin; SNEC, sinonasal epithelial cell; HDM, house dust mite; Nrf2, nuclear factor erythroid 2-related factor 2; ZO-1, zonula occludens-1; OVA, ovalbumin; TXNIP, thioredoxin-interacting protein; MDA, malondialdehyde; SOD, superoxide dismutase; IgE, immunoglobulin E; TNF- $\alpha$, tumor necrosis factor- $\alpha$; NALF, nasal lavage fluid; HO-1, heme oxygenase-1; NF- $\mathrm{B}$, nuclear factor kappa-light-chain-enhancer of activated B cells; ELISA, enzyme-linked immunosorbent assay; TRX, thioredoxin.

In several studies, the effect of sulforaphane was evaluated. A study in 2017 evaluated nasal epithelial cell barrier function after administration of sulforaphane [89]. In allergic rhinitis condition with house dust mite, epithelial junction protein, zonula occludens (ZO)-1 was decreased but restored after Nrf2 activation by sulforaphane. This was the first study to show that nasal epithelial cell barrier dysfunction in allergic rhinitis can be inhibited by activation of the Nrf2 pathway by sulforaphane treatment. Additionally, in a double-blinded, randomized, placebo-controlled clinical trial, sulforaphane showed effects in decreasing T2 cytokines such as IL-4, IL-5, and IL-13 in nasal cavity mucus of allergic rhinitis patients [94]. Subjective and objective parameters of allergic rhinitis such as total nasal symptom score (TNSS) and peak nasal inspiratory flow (PNIF) were improved after 3 weeks of sulforaphane treatment.

As mentioned in the previous section, the allergic rhinitis animal model study showed the effectiveness of resveratrol in reducing oxidative stress markers such as MDA [77]. TXNIP level was positively correlated with MDA levels but negatively correlated with SOD activities, implying that resveratrol treatment might decrease TXNIP levels, leading to attenuation of oxidative stress. Resveratrol was tested in a double-blinded, randomized, placebo-controlled study; patients who were administered with resveratrol showed a decrease in nasal symptoms, serum IgE, IL-4, TNF- $\alpha$, and eosinophil levels, compared to the placebo group [95]. The clinical effect of resveratrol in decreasing nasal symptoms has been reported before [99].

A mango extract, mangiferin, has also been the target in some studies. In the OVAinduced murine allergic rhinitis model, mice that were administered with mangiferin showed fewer nasal symptoms and nasal mucosa inflammation, and inflammatory cell infiltration and epithelial disruption were reduced in histopathology. In nasal lavage fluid (NALF), after mangiferin treatment, MDA level was reduced, SOD activity was increased, and Nrf2/HO-1 expression was upregulated, while expression of NF- $\mathrm{B}$ was decreased [82]. In another recent study with an allergic rhinitis animal model, after administration of mangiferin, MDA generation after allergen exposure was decreased. NF- $k \mathrm{~B}$ signaling pathway activation was prevented, leading to the downregulation of inflammatory cytokines such as TNF- $\alpha$ and IL-1 $\beta$. In histology, allergic rhinitis-related nasal epithelial changes such as ciliary loss and eosinophil infiltration were attenuated [83].

As described above, the study with a potential therapeutic antioxidant Piper nigrum extract evaluated the effect in the OVA-induced allergic rhinitis murine model [90]. The 
mice were orally administered with either Piper nigrum extract or dexamethasone. In mice treated with Piper nigrum extract, histamine release from mast cells, nasal symptoms, and eosinophil infiltration in nasal lavage fluid and nasal tissue were decreased. The result suggested that the antioxidant treatment promoted the cytoprotective function of the Nrf2 and heme oxygenase (HO)-1 signaling pathway, which resulted in inhibiting the disruption of tight junction proteins in the allergic rhinitis model.

Quercetin, a flavonoid, is known to yield a strong antioxidant property compared to other natural antioxidants. In allergic rhinitis patients, sinonasal epithelial cells were harvested and used to find their effectiveness [97]. In the study, after quercetin treatment, thioredoxin (TRX) production was increased in ELISA in response to $\mathrm{H}_{2} \mathrm{O}_{2}$ stimulation. Additionally, in OVA-sensitized mice, quercetin administration led to inhibition of nasal symptoms in allergic rhinitis mice. In nasal lavage fluids obtained $6 \mathrm{~h}$ after allergen challenge, TRX levels were increased.

Lastly, taurine was studied in allergic rhinitis patients and in the OVA-induced murine allergic rhinitis model [98]. Taurine administration showed a decrease in SOD3 level, nasal symptoms, inflammatory cytokine production, and inflammatory cell infiltration.

\section{Conclusions}

To study the effect of oxidative stress, transcriptional factors such as Nrf2 and NF- $\mathrm{B}$ have been investigated in murine models of allergic rhinitis as well as nasal mucosa epithelial cells of patients with allergic rhinitis. Several possible therapeutic antioxidants that are abundant in natural dietary sources have been studied and have shown promising results by inhibiting several oxidative stress pathway markers. As limitations exist with currently used treatment methods in allergic rhinitis patients, a more detailed understanding of oxidative stress and antioxidants in allergic rhinitis would lead to better control of the disease. Future studies with therapeutic antioxidants could focus on clinical studies of allergic rhinitis patients based on previous literature.

Author Contributions: Conceptualization, S.H.L. and T.H.K.; methodology, M.H. and T.H.K.; validation, M.H. and D.L.; investigation, M.H. and T.H.K.; resources, D.L.; data curation, M.H. and D.L.; writing-original draft preparation, M.H. and T.H.K.; writing-review and editing, M.H. and T.H.K.; visualization, M.H. and T.H.K.; supervision, S.H.L. and T.H.K.; project administration, T.H.K.; funding acquisition, T.H.K. All authors have read and agreed to the published version of the manuscript.

Funding: This research was supported by the Basic Science Research Program, National Research Foundation of Korea, funded by the Ministry of Science and Technology and the Ministry of Science, ICT \& Future Planning (2017R1A2B2003575, NRF-2020R1A2C1006398), the Ministry of Science and ICT (2020R1C1C1012288), Korea, under the ICT Creative Consilience program (IITP-20210018190011001) supervised by the IITP (Institute for Information \& Communications Technology Planning \& Evaluation), the Korea Health Technology R\&D Project (HI17C0387), Korea Health Industry Development Institute (KHIDI), and the Ministry of Health \& Welfare. This research was also supported by a Korea University grant and a grant from Korea University Medical Center and Anam Hospital, Seoul, Republic of Korea.

Acknowledgments: Figures were created with BioRender.com (accessed on 3 August 2021).

Conflicts of Interest: The authors declare no conflict of interest.

\section{References}

1. Sies, H.; Berndt, C.; Jones, D.P. Oxidative stress. Annu. Rev. Biochem. 2017, 86, 715-748. [CrossRef] [PubMed]

2. Frijhoff, J.; Winyard, P.G.; Zarkovic, N.; Davies, S.S.; Stocker, R.; Cheng, D.; Knight, A.R.; Taylor, E.L.; Oettrich, J.; Ruskovska, T.; et al. Clinical relevance of biomarkers of oxidative stress. Antioxid. Redox Signal. 2015, 23, 1144-1170. [CrossRef] [PubMed]

3. Bayer, S.B.; Maghzal, G.; Stocker, R.; Hampton, M.B.; Winterbourn, C.C. Neutrophil-mediated oxidation of erythrocyte peroxiredoxin 2 as a potential marker of oxidative stress in inflammation. FASEB J. Off. Publ. Fed. Am. Soc. Exp. Biol. 2013, 27, $3315-3322$

4. Samitas, K.; Carter, A.; Kariyawasam, H.H.; Xanthou, G. Upper and lower airway remodelling mechanisms in asthma, allergic rhinitis and chronic rhinosinusitis: The one airway concept revisited. Allergy 2018, 73, 993-1002. [CrossRef] 
5. Shamssain, M.H.; Shamsian, N. Prevalence and severity of asthma, rhinitis, and atopic eczema in 13- to 14-year-old schoolchildren from the northeast of england. Ann. Allergy Asthma Immunol. Off. Publ. Am. Coll. Allergy Asthma Immunol. 2001, 86, 428-432. [CrossRef]

6. Bousquet, J.; Annesi-Maesano, I.; Carat, F.; Léger, D.; Rugina, M.; Pribil, C.; El Hasnaoui, A.; Chanal, I. Characteristics of intermittent and persistent allergic rhinitis: Dreams study group. Clin. Exp. Allergy J. Br. Soc. Allergy Clin. Immunol. 2005, 35, 728-732. [CrossRef] [PubMed]

7. Linneberg, A.; Nielsen, N.H.; Madsen, F.; Frølund, L.; Dirksen, A.; Jørgensen, T. Increasing prevalence of specific ige to aeroallergens in an adult population: Two cross-sectional surveys 8 years apart: The copenhagen allergy study. J. Allergy Clin. Immunol. 2000, 106, 247-252. [CrossRef] [PubMed]

8. Bousquet, J.; Khaltaev, N.; Cruz, A.A.; Denburg, J.; Fokkens, W.J.; Togias, A.; Zuberbier, T.; Baena-Cagnani, C.E.; Canonica, G.W.; van Weel, C.; et al. Allergic rhinitis and its impact on asthma (aria) 2008 update (in collaboration with the world health organization, ga(2)len and allergen). Allergy 2008, 63 (Suppl. S86), 8-160. [CrossRef]

9. Asher, M.I.; Montefort, S.; Björkstén, B.; Lai, C.K.; Strachan, D.P.; Weiland, S.K.; Williams, H. Worldwide time trends in the prevalence of symptoms of asthma, allergic rhinoconjunctivitis, and eczema in childhood: Isaac phases one and three repeat multicountry cross-sectional surveys. Lancet 2006, 368, 733-743. [CrossRef]

10. Lee, S.L.; Wong, W.; Lau, Y.L. Increasing prevalence of allergic rhinitis but not asthma among children in hong kong from 1995 to 2001 (phase 3 international study of asthma and allergies in childhood). Pediatric Allergy Immunol. Off. Publ. Eur. Soc. Pediatric Allergy Immunol. 2004, 15, 72-78. [CrossRef]

11. Reed, S.D.; Lee, T.A.; McCrory, D.C. The economic burden of allergic rhinitis: A critical evaluation of the literature. Pharmacoeconomics 2004, 22, 345-361. [CrossRef]

12. Greiner, A.N.; Hellings, P.W.; Rotiroti, G.; Scadding, G.K. Allergic rhinitis. Lancet 2011, 378, 2112-2122. [CrossRef]

13. Meltzer, E.O. Allergic rhinitis: Burden of illness, quality of life, comorbidities, and control. Immunol. Allergy Clin. North Am. 2016, 36, 235-248. [CrossRef] [PubMed]

14. Leynaert, B.; Neukirch, C.; Liard, R.; Bousquet, J.; Neukirch, F. Quality of life in allergic rhinitis and asthma. A population-based study of young adults. Am. J. Respir. Crit. Care Med. 2000, 162, 1391-1396. [CrossRef] [PubMed]

15. Meltzer, E.O.; Blaiss, M.S.; Derebery, M.J.; Mahr, T.A.; Gordon, B.R.; Sheth, K.K.; Simmons, A.L.; Wingertzahn, M.A.; Boyle, J.M. Burden of allergic rhinitis: Results from the pediatric allergies in america survey. J. Allergy Clin. Immunol. 2009, 124, S43-S70. [CrossRef]

16. White, P.; Smith, H.; Baker, N.; Davis, W.; Frew, A. Symptom control in patients with hay fever in uk general practice: How well are we doing and is there a need for allergen immunotherapy? Clin. Exp. Allergy J. Br. Soc. Allergy Clin. Immunol. 1998, 28, 266-270. [CrossRef]

17. Durham, S.R.; Penagos, M. Sublingual or subcutaneous immunotherapy for allergic rhinitis? J. Allergy Clin. Immunol. 2016, 137, 339-349.e10. [CrossRef] [PubMed]

18. Sies, H. Oxidative stress: Concept and some practical aspects. Antioxidants 2020, 9, 852. [CrossRef] [PubMed]

19. Lushchak, V.I. Free radicals, reactive oxygen species, oxidative stress and its classification. Chem. Biol. Interact. 2014, 224, 164-175. [CrossRef] [PubMed]

20. Yan, L.J. Positive oxidative stress in aging and aging-related disease tolerance. Redox Biol. 2014, 2, 165-169. [CrossRef] [PubMed]

21. Sies, H. Hydrogen peroxide as a central redox signaling molecule in physiological oxidative stress: Oxidative eustress. Redox Biol. 2017, 11, 613-619. [CrossRef]

22. Ray, P.D.; Huang, B.W.; Tsuji, Y. Reactive oxygen species (ros) homeostasis and redox regulation in cellular signaling. Cell. Signal. 2012, 24, 981-990. [CrossRef]

23. Birben, E.; Sahiner, U.M.; Sackesen, C.; Erzurum, S.; Kalayci, O. Oxidative stress and antioxidant defense. World Allergy Organ. J. 2012, 5, 9-19. [CrossRef]

24. Church, D.F.; Pryor, W.A. Free-radical chemistry of cigarette smoke and its toxicological implications. Environ. Health Perspect. 1985, 64, 111-126. [CrossRef]

25. Freudenthal, B.D.; Beard, W.A.; Perera, L.; Shock, D.D.; Kim, T.; Schlick, T.; Wilson, S.H. Uncovering the polymerase-induced cytotoxicity of an oxidized nucleotide. Nature 2015, 517, 635-639. [CrossRef] [PubMed]

26. Leon, J.; Sakumi, K.; Castillo, E.; Sheng, Z.; Oka, S.; Nakabeppu, Y. 8-oxoguanine accumulation in mitochondrial DNA causes mitochondrial dysfunction and impairs neuritogenesis in cultured adult mouse cortical neurons under oxidative conditions. Sci. Rep. 2016, 6, 22086. [CrossRef]

27. Davies, M.J. Protein oxidation and peroxidation. Biochem. J. 2016, 473, 805-825. [CrossRef] [PubMed]

28. Kelly, F.J.; Mudway, I.S. Protein oxidation at the air-lung interface. Amino Acids 2003, 25, 375-396. [CrossRef] [PubMed]

29. Stadtman, E.R. Metal ion-catalyzed oxidation of proteins: Biochemical mechanism and biological consequences. Free Radic. Biol. Med. 1990, 9, 315-325. [CrossRef]

30. Ghezzi, P. Environmental risk factors and their footprints in vivo-A proposal for the classification of oxidative stress biomarkers. Redox Biol. 2020, 34, 101442. [CrossRef]

31. Siu, G.M.; Draper, H.H. Metabolism of malonaldehyde in vivo and in vitro. Lipids 1982, 17, 349-355. [CrossRef]

32. Karadogan, B.; Beyaz, S.; Gelincik, A.; Buyukozturk, S.; Arda, N. Evaluation of oxidative stress biomarkers and antioxidant parameters in allergic asthma patients with different level of asthma control. J. Asthma Off. J. Assoc. Care Asthma 2021. [CrossRef] 
33. Hoffmann, F.; Ender, F.; Schmudde, I.; Lewkowich, I.P.; Köhl, J.; König, P.; Laumonnier, Y. Origin, localization, and immunoregulatory properties of pulmonary phagocytes in allergic asthma. Front. Immunol. 2016, 7, 107. [CrossRef] [PubMed]

34. Mishra, V.; Banga, J.; Silveyra, P. Oxidative stress and cellular pathways of asthma and inflammation: Therapeutic strategies and pharmacological targets. Pharmacol. Ther. 2018, 181, 169-182. [CrossRef] [PubMed]

35. Mortaz, E.; Adcock, I.M.; Ito, K.; Kraneveld, A.D.; Nijkamp, F.P.; Folkerts, G. Cigarette smoke induces cxcl8 production by human neutrophils via activation of tlr9 receptor. Eur. Respir. J. 2010, 36, 1143-1154. [CrossRef] [PubMed]

36. Cosio, M.G.; Saetta, M.; Agusti, A. Immunologic aspects of chronic obstructive pulmonary disease. N. Engl. J. Med. 2009, 360, 2445-2454. [CrossRef]

37. Li, Q.; Engelhardt, J.F. Interleukin-1beta induction of nfkappab is partially regulated by h2o2-mediated activation of nfkappabinducing kinase. J. Biol. Chem. 2006, 281, 1495-1505. [CrossRef]

38. Rahman, I.; MacNee, W. Role of transcription factors in inflammatory lung diseases. Thorax 1998, 53, 601-612. [CrossRef]

39. Mizumura, K.; Maruoka, S.; Shimizu, T.; Gon, Y. Role of nrf2 in the pathogenesis of respiratory diseases. Respir. Investig. 2020, 58, 28-35. [CrossRef]

40. Shintani, Y.; Maruoka, S.; Gon, Y.; Koyama, D.; Yoshida, A.; Kozu, Y.; Kuroda, K.; Takeshita, I.; Tsuboi, E.; Soda, K.; et al. Nuclear factor erythroid 2-related factor 2 (nrf2) regulates airway epithelial barrier integrity. Allergol. Int. Off. J. Jpn. Soc. Allergol. 2015, 64, S54-S63. [CrossRef] [PubMed]

41. Sayers, I.; Hall, I.P. Pharmacogenetic approaches in the treatment of asthma. Curr. Allergy Asthma Rep. 2005, 5, 101-108. [CrossRef]

42. Barnes, P.J. New anti-inflammatory targets for chronic obstructive pulmonary disease. Nat. Rev. Drug Discov. 2013, 12, 543-559. [CrossRef]

43. Belvisi, M.G.; Hele, D.J.; Birrell, M.A. New anti-inflammatory therapies and targets for asthma and chronic obstructive pulmonary disease. Expert Opin. Targets 2004, 8, 265-285. [CrossRef] [PubMed]

44. Gong, J.H.; Shin, D.; Han, S.Y.; Park, S.H.; Kang, M.K.; Kim, J.L.; Kang, Y.H. Blockade of airway inflammation by kaempferol via disturbing tyk-stat signaling in airway epithelial cells and in asthmatic mice. Evid. Based Complementary Altern. Med. Ecam 2013, 2013, 250725. [CrossRef] [PubMed]

45. Hosseini, S.; Pishnamazi, S.; Sadrzadeh, S.M.; Farid, F.; Farid, R.; Watson, R.R. Pycnogenol((r)) in the management of asthma. J. Med. Food 2001, 4, 201-209. [CrossRef] [PubMed]

46. Lau, B.H.; Riesen, S.K.; Truong, K.P.; Lau, E.W.; Rohdewald, P.; Barreta, R.A. Pycnogenol as an adjunct in the management of childhood asthma. J. Asthma Off. J. Assoc. Care Asthma 2004, 41, 825-832. [CrossRef]

47. Sbodio, J.I.; Snyder, S.H.; Paul, B.D. Redox mechanisms in neurodegeneration: From disease outcomes to therapeutic opportunities. Antioxid. Redox Signal. 2019, 30, 1450-1499. [CrossRef] [PubMed]

48. Bradley-Whitman, M.A.; Timmons, M.D.; Beckett, T.L.; Murphy, M.P.; Lynn, B.C.; Lovell, M.A. Nucleic acid oxidation: An early feature of alzheimer's disease. J. Neurochem. 2014, 128, 294-304. [CrossRef]

49. Chauhan, A.; Gu, F.; Essa, M.M.; Wegiel, J.; Kaur, K.; Brown, W.T.; Chauhan, V. Brain region-specific deficit in mitochondrial electron transport chain complexes in children with autism. J. Neurochem. 2011, 117, 209-220. [CrossRef] [PubMed]

50. Hardan, A.Y.; Fung, L.K.; Libove, R.A.; Obukhanych, T.V.; Nair, S.; Herzenberg, L.A.; Frazier, T.W.; Tirouvanziam, R. A randomized controlled pilot trial of oral n-acetylcysteine in children with autism. Biol. Psychiatry 2012, 71, 956-961. [CrossRef]

51. Dolske, M.C.; Spollen, J.; McKay, S.; Lancashire, E.; Tolbert, L. A preliminary trial of ascorbic acid as supplemental therapy for autism. Prog. Neuro-Psychopharmacol. Biol. Psychiatry 1993, 17, 765-774. [CrossRef]

52. Jones, D.P.; Sies, H. The redox code. Antioxid. Redox Signal. 2015, 23, 734-746. [CrossRef]

53. Kattoor, A.J.; Pothineni, N.V.K.; Palagiri, D.; Mehta, J.L. Oxidative stress in atherosclerosis. Curr. Atheroscler. Rep. 2017, 19, 42. [CrossRef]

54. Senoner, T.; Dichtl, W. Oxidative stress in cardiovascular diseases: Still a therapeutic target? Nutrients 2019, 11, 2090. [CrossRef] [PubMed]

55. Samadi, A.; Sabuncuoglu, S.; Samadi, M.; Isikhan, S.Y.; Chirumbolo, S.; Peana, M.; Lay, I.; Yalcinkaya, A.; Bjørklund, G. A comprehensive review on oxysterols and related diseases. Curr. Med. Chem. 2021, 28, 110-136. [CrossRef] [PubMed]

56. Marchio, P.; Guerra-Ojeda, S.; Vila, J.M.; Aldasoro, M.; Victor, V.M.; Mauricio, M.D. Targeting early atherosclerosis: A focus on oxidative stress and inflammation. Oxidative Med. Cell. Longev. 2019, 2019, 8563845. [CrossRef]

57. Chen, X.Q.; Hu, T.; Han, Y.; Huang, W.; Yuan, H.B.; Zhang, Y.T.; Du, Y.; Jiang, Y.W. Preventive effects of catechins on cardiovascular disease. Molecules 2016, 21, 1759. [CrossRef] [PubMed]

58. McCullough, M.L.; Peterson, J.J.; Patel, R.; Jacques, P.F.; Shah, R.; Dwyer, J.T. Flavonoid intake and cardiovascular disease mortality in a prospective cohort of us adults. Am. J. Clin. Nutr. 2012, 95, 454-464. [CrossRef]

59. Schwingshackl, L.; Hoffmann, G. Mediterranean dietary pattern, inflammation and endothelial function: A systematic review and meta-analysis of intervention trials. Nutr. Metab. Cardiovasc. Dis. NMCD 2014, 24, 929-939. [CrossRef]

60. Ditano-Vázquez, P.; Torres-Peña, J.D.; Galeano-Valle, F.; Pérez-Caballero, A.I.; Demelo-Rodríguez, P.; Lopez-Miranda, J.; Katsiki, N.; Delgado-Lista, J.; Alvarez-Sala-Walther, L.A. The fluid aspect of the mediterranean diet in the prevention and management of cardiovascular disease and diabetes: The role of polyphenol content in moderate consumption of wine and olive oil. Nutrients 2019, 11, 2833. [CrossRef]

61. Hayes, J.D.; Dinkova-Kostova, A.T.; Tew, K.D. Oxidative stress in cancer. Cancer Cell 2020, 38, 167-197. [CrossRef] 
62. Sosa, V.; Moliné, T.; Somoza, R.; Paciucci, R.; Kondoh, H.; ME, L.L. Oxidative stress and cancer: An overview. Ageing Res. Rev. 2013, 12, 376-390. [CrossRef]

63. Rao, Y.; Li, R.; Zhang, D. A drug from poison: How the therapeutic effect of arsenic trioxide on acute promyelocytic leukemia was discovered. Sci. China. Life Sci. 2013, 56, 495-502. [CrossRef] [PubMed]

64. Reczek, C.R.; Chandel, N.S. Revisiting vitamin c and cancer. Science 2015, 350, 1317-1318. [CrossRef] [PubMed]

65. Kirkpatrick, D.L.; Powis, G. Clinically evaluated cancer drugs inhibiting redox signaling. Antioxid. Redox Signal. 2017, 26, 262-273. [CrossRef]

66. Sin, B.; Togias, A. Pathophysiology of allergic and nonallergic rhinitis. Proc. Am. Thorac. Soc. 2011, 8, 106-114. [CrossRef] [PubMed]

67. Wheatley, L.M.; Togias, A. Clinical practice. Allergic rhinitis. N. Engl. J. Med. 2015, 372, 456-463. [CrossRef] [PubMed]

68. Van den Oord, R.A.; Sheikh, A. Filaggrin gene defects and risk of developing allergic sensitisation and allergic disorders: Systematic review and meta-analysis. BMJ 2009, 339, b2433. [CrossRef]

69. Lei, X.G.; Zhu, J.H.; Cheng, W.H.; Bao, Y.; Ho, Y.S.; Reddi, A.R.; Holmgren, A.; Arnér, E.S. Paradoxical roles of antioxidant enzymes: Basic mechanisms and health implications. Physiol. Rev. 2016, 96, 307-364. [CrossRef]

70. Cunningham, G.M.; Roman, M.G.; Flores, L.C.; Hubbard, G.B.; Salmon, A.B.; Zhang, Y.; Gelfond, J.; Ikeno, Y. The paradoxical role of thioredoxin on oxidative stress and aging. Arch. Biochem. Biophys. 2015, 576, 32-38. [CrossRef]

71. Miller, D.M.; Buettner, G.R.; Aust, S.D. Transition metals as catalysts of "autoxidation" reactions. Free Radic. Biol. Med. 1990, 8, 95-108. [CrossRef]

72. Henzler, T.; Steudle, E. Transport and metabolic degradation of hydrogen peroxide in chara corallina: Model calculations and measurements with the pressure probe suggest transport of $\mathrm{H}_{(2)} \mathrm{O}_{(2)}$ across water channels. J. Exp. Bot. 2000, 51, 2053-2066. [CrossRef]

73. Marinho, H.S.; Real, C.; Cyrne, L.; Soares, H.; Antunes, F. Hydrogen peroxide sensing, signaling and regulation of transcription factors. Redox Biol. 2014, 2, 535-562. [CrossRef]

74. Ma, Q. Role of nrf2 in oxidative stress and toxicity. Annu. Rev. Pharmacol. Toxicol. 2013, 53, 401-426. [CrossRef] [PubMed]

75. Itoh, K.; Chiba, T.; Takahashi, S.; Ishii, T.; Igarashi, K.; Katoh, Y.; Oyake, T.; Hayashi, N.; Satoh, K.; Hatayama, I.; et al. An $\mathrm{nrf} 2 /$ small maf heterodimer mediates the induction of phase ii detoxifying enzyme genes through antioxidant response elements. Biochem. Biophys. Res. Commun. 1997, 236, 313-322. [CrossRef] [PubMed]

76. Cebula, M.; Schmidt, E.E.; Arnér, E.S. Trxr1 as a potent regulator of the nrf2-keap1 response system. Antioxid. Redox Signal. 2015, 23, 823-853. [CrossRef] [PubMed]

77. Zhang, W.; Tang, R.; Ba, G.; Li, M.; Lin, H. Anti-allergic and anti-inflammatory effects of resveratrol via inhibiting txnip-oxidative stress pathway in a mouse model of allergic rhinitis. World Allergy Organ. J. 2020, 13, 100473. [CrossRef] [PubMed]

78. Schreck, R.; Rieber, P.; Baeuerle, P.A. Reactive oxygen intermediates as apparently widely used messengers in the activation of the nf-kappa b transcription factor and hiv-1. EMBO J. 1991, 10, 2247-2258. [CrossRef]

79. Perkins, N.D. Integrating cell-signalling pathways with nf-kappab and ikk function. Nat. Rev. Mol. Cell Biol. 2007, 8, 49-62. [CrossRef]

80. Pande, V.; Ramos, M.J. Molecular recognition of 15-deoxy-delta(12,14)-prostaglandin j2 by nuclear factor-kappa b and other cellular proteins. Bioorganic Med. Chem. Lett. 2005, 15, 4057-4063. [CrossRef] [PubMed]

81. Seyedsadjadi, N.; Grant, R. The potential benefit of monitoring oxidative stress and inflammation in the prevention of noncommunicable diseases (ncds). Antioxidants 2020, 10, 15. [CrossRef]

82. Piao, C.H.; Fan, Y.J.; Nguyen, T.V.; Song, C.H.; Chai, O.H. Mangiferin alleviates ovalbumin-induced allergic rhinitis via nrf2/ho1/nf-kb signaling pathways. Int. J. Mol. Sci. 2020, 21, 3415. [CrossRef] [PubMed]

83. Wang, Y.; Cui, C.; Sun, H. Anti-inflammatory effect of mangiferin on an experimental model of allergic rhinitis through the inhibition of nf-kb signaling pathways. J. Environ. Pathol. Toxicol. Oncol. Off. Organ Int. Soc. Environ. Toxicol. Cancer 2020, 39, 357-364. [CrossRef]

84. Mattila, P.; Joenväärä, S.; Renkonen, J.; Toppila-Salmi, S.; Renkonen, R. Allergy as an epithelial barrier disease. Clin. Transl. Allergy 2011, 1, 5. [CrossRef]

85. Van Gerven, L.; Boeckxstaens, G.; Hellings, P. Up-date on neuro-immune mechanisms involved in allergic and non-allergic rhinitis. Rhinology 2012, 50, 227-235. [CrossRef]

86. Siti Sarah, C.O.; Md Shukri, N.; Mohd Ashari, N.S.; Wong, K.K. Zonula occludens and nasal epithelial barrier integrity in allergic rhinitis. PeerJ 2020, 8, e9834. [CrossRef] [PubMed]

87. Steelant, B.; Farré, R.; Wawrzyniak, P.; Belmans, J.; Dekimpe, E.; Vanheel, H.; Van Gerven, L.; Kortekaas Krohn, I.; Bullens, D.M.A.; Ceuppens, J.L.; et al. Impaired barrier function in patients with house dust mite-induced allergic rhinitis is accompanied by decreased occludin and zonula occludens-1 expression. J. Allergy Clin. Immunol. 2016, 137, 1043-1053.e5. [CrossRef] [PubMed]

88. Beutel, O.; Maraspini, R.; Pombo-García, K.; Martin-Lemaitre, C.; Honigmann, A. Phase separation of zonula occludens proteins drives formation of tight junctions. Cell 2019, 179, 923-936.e11. [CrossRef]

89. London, N.R., Jr.; Tharakan, A.; Lane, A.P.; Biswal, S.; Ramanathan, M., Jr. Nuclear erythroid 2-related factor 2 activation inhibits house dust mite-induced sinonasal epithelial cell barrier dysfunction. Int. Forum Allergy Rhinol. 2017, 7, 536-541. [CrossRef] [PubMed] 
90. Bui, T.T.; Fan, Y.; Piao, C.H.; Nguyen, T.V.; Shin, D.U.; Jung, S.Y.; Hyeon, E.; Song, C.H.; Lee, S.Y.; Shin, H.S.; et al. Piper nigrum extract improves ova-induced nasal epithelial barrier dysfunction via activating nrf2/ho-1 signaling. Cell. Immunol. 2020, 351, 104035. [CrossRef]

91. Reuter, S.; Gupta, S.C.; Chaturvedi, M.M.; Aggarwal, B.B. Oxidative stress, inflammation, and cancer: How are they linked? Free Radic. Biol. Med. 2010, 49, 1603-1616. [CrossRef] [PubMed]

92. Barnes, P.J. Oxidative stress-based therapeutics in copd. Redox Biol. 2020, 33, 101544. [CrossRef] [PubMed]

93. Fão, L.; Mota, S.I.; Rego, A.C. Shaping the nrf2-are-related pathways in alzheimer's and parkinson's diseases. Ageing Res. Rev. 2019, 54, 100942. [CrossRef] [PubMed]

94. Yusin, J.; Wang, V.; Henning, S.M.; Yang, J.; Tseng, C.H.; Thames, G.; Arnold, I.; Heber, D.; Lee, R.P.; Sanavio, L.; et al. The effect of broccoli sprout extract on seasonal grass pollen-induced allergic rhinitis. Nutrients 2021, 13, 1337. [CrossRef] [PubMed]

95. Lv, C.; Zhang, Y.; Shen, L. Preliminary clinical effect evaluation of resveratrol in adults with allergic rhinitis. Int. Arch. Allergy Immunol. 2018, 175, 231-236. [CrossRef]

96. Bui, T.T.; Piao, C.H.; Hyeon, E.; Fan, Y.; Choi, D.W.; Jung, S.Y.; Jang, B.H.; Shin, H.S.; Song, C.H.; Chai, O.H. Preventive effect of bupleurum chinense on nasal inflammation via suppressing thelper type 2, eosinophil and mast cell activation. Am. J. Chin. Med. 2019, 47, 405-421. [CrossRef]

97. Edo, Y.; Otaki, A.; Asano, K. Quercetin enhances the thioredoxin production of nasal epithelial cells in vitro and in vivo. Medicines 2018, 5, 124. [CrossRef]

98. Zhou, J.; Lu, Y.; Li, F.; Wu, W.; Xie, D.; Feng, Y. In vitro and in vivo antiallergic effects of taurine on allergic rhinitis. Int. Arch. Allergy Immunol. 2020, 181, 404-416. [CrossRef]

99. Miraglia Del Giudice, M.; Maiello, N.; Capristo, C.; Alterio, E.; Capasso, M.; Perrone, L.; Ciprandi, G. Resveratrol plus carboxymethyl- $\beta$-glucan reduces nasal symptoms in children with pollen-induced allergic rhinitis. Curr. Med Res. Opin. 2014, 30, 1931-1935. [CrossRef] [PubMed] 